\title{
Feeding and body condition of an invasive fish species under different environmental conditions
}

\author{
Laryssa H. R. Pazianoto, Vivian de M. Cionek, Fábio N. O. Fogaça and \\ Evanilde Benedito
}

Diet, energy density (ED) and relative condition factor $(K n)$ were used to investigate the energetic assimilation of the invasive fish Hemiodus orthonops under different environmental condition of the upper rio Paraná floodplain. Samples were taken in June and September 2013 and 2014. Nutrient content was determined for sediment. The diet was combined in the Food Index (IAi\%), ED was expressed in Kcal/g of dry weight and $K n$ was calculated by: $\mathrm{K}_{\mathrm{n}}=\mathrm{Wt} / \mathrm{We}$, where Wt is the total weight and We the expected weight. Detritus/sediment prevailed in the stomachs of specimens from Ivinhema and Baia, while Algae was the main item in Paraná, reflecting the resource availability. ED and $K n$ from Ivinhema specimens were the greatest, consequence of the quality of food and lower spent on searching and handling food. The Paraná specimens showed lower ED values, but higher $K n$ values, due to algae consumption, a nutrient-rich resource. Baia presented high aluminum concentration on the sediment and the lower $\mathrm{pH}$ values, which contribute to reduce the nutritional value of the detritus and the ED and $K n$ values of their specimens. In conclusion, $H$. orthonops is capable to take advantage of the resources availability in the different environments, ensuring their establishment.

Análise de dieta, densidade energética (DE) e fator de condição relativo $(K n)$ foram utilizados para investigar a assimilação energética do peixe invasor Hemiodus orthonops sob diferentes condições ambientais da planície de inundação do alto rio Paraná. As coletas ocorreram em junho e setembro de 2013 e 2014. O teor de nutrientes foi obtido para o sedimento. A dieta foi combinada no Índice Alimentar (IAi\%), a DE foi expressa em Kcal/g de peso seco, o Kn foi calculado através de: $\mathrm{K}_{\mathrm{n}}=\mathrm{Wt} / \mathrm{We}$, onde Wt é o peso total e We o peso esperado. Detrito/sedimento prevaleceu nos estômagos dos espécimes do Ivinhema e Baía, enquanto Alga foi o principal item no Paraná, refletindo a disponibilidade de recursos. A DE e Kn dos indivíduos do Ivinhema foram os maiores, consequência da qualidade do alimento e do menor gasto em procura e manipulação do alimento. Os indivíduos do Paraná registraram os menores valores de DE, mas elevados valores de $K n$, devido ao consumo de alga, um recurso alimentar rico em nutrientes. Baía apresentou elevada concentração de alumínio no sedimento e reduzidos valores de $\mathrm{pH}$, o que contribuiu com a redução do valor nutricional do detrito e dos valores de DE e Kn dos indivíduos. Concluindo, H. orthonops é capaz de se beneficiar da disponibilidade de recursos nos diferentes ambientes, garantindo seu estabelecimento.

Keywords: Biological invasions, Detritivory, Energetic density, Hemiodus orthonops, Relative condition factor.

\section{Introduction}

Introduction of species in natural environments is one of the most serious threats to biodiversity (Clavero \& García Berthou, 2005; Davis, 2009; Vitule \& Prodocimo, 2012). Some of the main goals and challenges of invasion biology are to predict which environments are more susceptible to invasions and to identify the factors responsible for the establishment of a species (Marchetti et al., 2004; Taylor $\&$ Irwin, 2004). The success of invasive fish species has been linked to the deleterious effects of human activities
(Taylor \& Irwin, 2004; Leprieur et al., 2008) that promote greater temporal and spatial variability of physicochemical characteristics (Havel et al., 2005; Johnson et al., 2008). Such variability favors non-native species due to higher tolerance to changes in physicochemical characteristics and plasticity of life history traits such as diet and reproduction (Marchetti et al., 2004; Gutierre et al., 2014; Santos et al., 2014).

The upper rio Paraná floodplain represents an important economic, ecological and recreational system in South Brazil. Its preserved stretch is mainly represented by

Programa de Pós-Graduação em Ecologia de Ambientes Aquáticos Continentais, Núcleo de Pesquisas em Limnologia, Ictiologia e Aquicultura (Nupélia), Universidade Estadual de Maringá (UEM). Av. Colombo 5790, 87020-900 Maringá, Paraná, Brazil. (LHRP) lary.pazianoto@hotmail.com (corresponding author), (VMC) viviancionek@gmail.com, (FNOF) fabiofogacinha@gmail.com, (EB) eva@nupelia.uem.br 
three subsystems; all composed of a major river channel and lateral lakes and backwaters. The principal subsystem is Paraná, and its tributaries are known as Ivinhema and Baía. Despite the great importance of these systems, they are one of the most affected by human activities in the country (Agostinho et al., 2007; 2008). Among the common impacts detected in the region are the progressive increase of nutrient loading and biocides (Tank et al., 2010), erosion and sedimentation (Holanda et al., 2005) and discharge of domestic and industrial sewage (Finstad et al., 2007; Fucík et al., 2014). However, damming for hydroelectrical porpoises in recent decades represents the main impact in this region, reaching up for 145 reservoirs in the whole basin (Agostinho et al., 2007; 2008). The intense fragmentation of habitats and changes in physicochemical characteristics caused by the reservoirs facilitate the introduction and establishment of non-native fish species (Havel et al., 2005; Johnson et al., 2008). Thirty-three species of fish originating from the lower rio Paraná are established in the upper rio Paraná (Júlio Júnior et al., 2009) due to the formation of Itaipu Reservoir in 1982. It flooded the Salto de Sete Quedas and eliminated a natural geographic barrier. In 2002 a fish transposition channel ("Canal da Piracema") was built in Itaipu, that can be consider an ecological trap, because besides preventing the effective recruitment of some fishes (Pelicice \& Agostinho, 2008), additional species were able to disperse and reach the upper rio Paraná (Júlio-Júnior et al., 2009; Vitule et al., 2012). Among them Hemiodus orthonops Eigenmann \& Kennedy, 1903 was first recorded in the region in 2008. The species is endemic to the Paraná-Paraguay basin and showed rapid colonization and high abundance in the invaded area, reaching about $10 \%$ of catching effort in the subsequent six years (Agostinho et al., 2015). Despite being considered a detritivorous species in its natural range (Corrêa et al., 2009), the consumption of aquatic macrophytes and the dominance of periphytic algae in their diet were found only in the invaded region, mainly in the rio Paraná channel (Agostinho et al., 2015). On the other hand, the consumption of detritus/sediment was prominent in Ivinhema and Baía subsystems (Agostinho et al., 2015).

Acquisition of food resources and consequent energy assimilation directly affects the physiological characteristics of individuals and define the permanence of a species in a given environment (Zambrano et al., 2010). Changes in environmental characteristics may change the availability of food resources, causing species to modify its diet seeking to maximize energy gain (MacArthur \& Pianka, 1966). Thus, consumers capable of feeding more efficiently and optimize their energy uptake, will maximize their ecological fitness and contribute with more genes for future generations (Kahilainen \& Lehtonen, 2003). Understanding the use of food resources and the body condition of fish under the influence of environmental characteristics is an important prediction tool, which may indicate susceptible sites to species invasions.
Direct and indirect measures of energy allocation (i.e. energy density and relative condition factor), together with stomach content analysis can contribute to the understanding of these patterns. The energy density analysis can be used for various purposes, from prediction of bioenergetic and growth models, as well as consumption of food resources, since the tissues of organisms directly reflect the ingested food (Dourado \& Benedito-Cecilio, 2005; Tirelli et al., 2006). The relative condition factor is an indirect measure of the use of energy reserves. It reflects the fatness or the general well-being of an individual, since heavier individuals in a given length are considered in better body condition than lighter individuals with the same length (Peig \& Green, 2010; Miller et al., 2015).

The aim of this study was to asses for energy assimilation and overall wellbeing of the invasive fish species $H$. orthonops in the upper rio Paraná floodplain. The species occur throughout the floodplain. However, the subsystems present different limnological and physical characteristics due to natural features and mostly to the differential magnitude and types of impacts. Such environmental differences should be reflected in the species feeding preferences and energy assimilation, so we expect that $H$. orthonops populations shall present differential feeding behavior and energy assimilation in each of the subsystems. By assuming that Paraná subsystem presents greater predisposition to invasion of non-native species, while its tributaries (Baia and Ivinhema) are less predisposed due to lower hydro-electrical impact intensity (Taylor \& Irwin, 2004), we tested the hypothesis that $H$. orthonops populations present better energetic and overall wellbeing in the least impacted subsystems (Ivinhema and Baía). We expect that the tributaries, as least affected by hydro-electrical impacts, shall provide more diverse feeding resources and habitat diversity, and consequently, provide more suitable environment to the establishment of the species.

\section{Material and Methods}

Study area. Samples were conducted in the upper rio Paraná floodplain between the dam of Porto Primavera and the Itaipu reservoir. The floodplain is composed of three major subsystems, each of which features a main lotic channel (i.e. the river) and adjacent lakes and backwaters. The main subsystem of the floodplain is Paraná $\left(22^{\circ} 45^{\prime} \mathrm{S}\right.$; $53^{\circ} 15^{\prime} \mathrm{W}$ ) that is composed of the rio Paraná, Garças Lake and Pau Véio backwater. The remaining are tributaries of the Paraná subsystem. Ivinhema subsystem (2247’S; $53^{\circ} 32^{\prime} \mathrm{W}$ ) is composed of the Ivinhema River, Ventura Lake

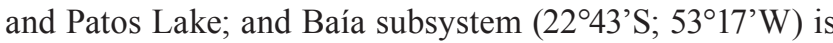
composed of the Baía River, Fechada Lake and Guaraná Lake (Fig. 1). The selected environments (i.e. river channel, lakes and backwaters) are included in the Long-Term Ecological Research Program (LTERP) - site 6. Sampling methodology was standardized along all environments allowing for direct comparisons. 
Paraná subsystem is characterized by higher water transparency, reaching up to 3 meters (obtained with Secchi disk); and the lowest concentrations of total phosphorus (12 $\left.\mu \mathrm{g} . \mathrm{L}^{-1}\right)$ and total nitrogen $\left(372 \mu \mathrm{g} . \mathrm{L}^{-1}\right)$. These patterns have been related to the existing cascade of reservoirs upstream of the floodplain, which retain sediment and nutrients and modifies the dynamics of the entire system (Roberto et al., 2009). High water transparency may also explain the distribution or establishment of species in the floodplain. Increased water transparency favors the dominance of algae and/or submerged aquatic macrophytes (Thomaz et al., 2009) and the success of visual predators such as Cichla kelberi Kullander and Ferreira, 2006 (Fugi et al., 2008), both observed only in the Paraná subsystem environments.

On the other hand, the Ivinhema and Baía subsystems present lower average transparency $(0.7 \mathrm{~m}$ and $0.8 \mathrm{~m}$, respectively) and the highest concentrations of total phosphorus (39 $\mu \mathrm{g} . \mathrm{L}^{-1}$ in Ivinhema and $38 \mu \mathrm{g} . \mathrm{L}^{-1}$ in Baía) and total nitrogen $\left(440 \mu \mathrm{g} . \mathrm{L}^{-1}\right.$ in Ivinhema and $566 \mu \mathrm{g} . \mathrm{L}^{-1}$ in Baía). Both systems features protected riparian cover and are less subjected to the effects of the reservoirs (Agostinho et al., 2004). Ivinhema subystem is under the protection of the State Park of Ivinhema Lowland (Arenas-Ibarra et al., 2012) and presents high input of allochthonous material, as well as production and availability of organic detritus (Azevedo et al., 2008). Baia subsystem decaying organic matter from adjacent vegetation induces slightly acidic water (i.e. $\mathrm{pH}=6.5$ ) (Roberto et al., 2009). Such features from both systems suggests higher particulate organic matter in the water column as possible resources for the entire food web, which might contribute to the dynamics and maintenance of the nutrient levels of its associated environments. These features together contribute to the maintenance of favorable environments to fishes, reflecting on reproduction and growth. Authors as Suzuki et al. (2009), for example, emphasize the importance of these two subsystems for spawning and early development of juveniles, especially of migratory species, as well as obtaining food and shelter. Moreover, these two subsystems are characterized by having greater richness and diversity of speciesin addition to high catch individuals in relation to the Paraná subsystem, indicating higher habitat quality (Fernandes et al., 2009).

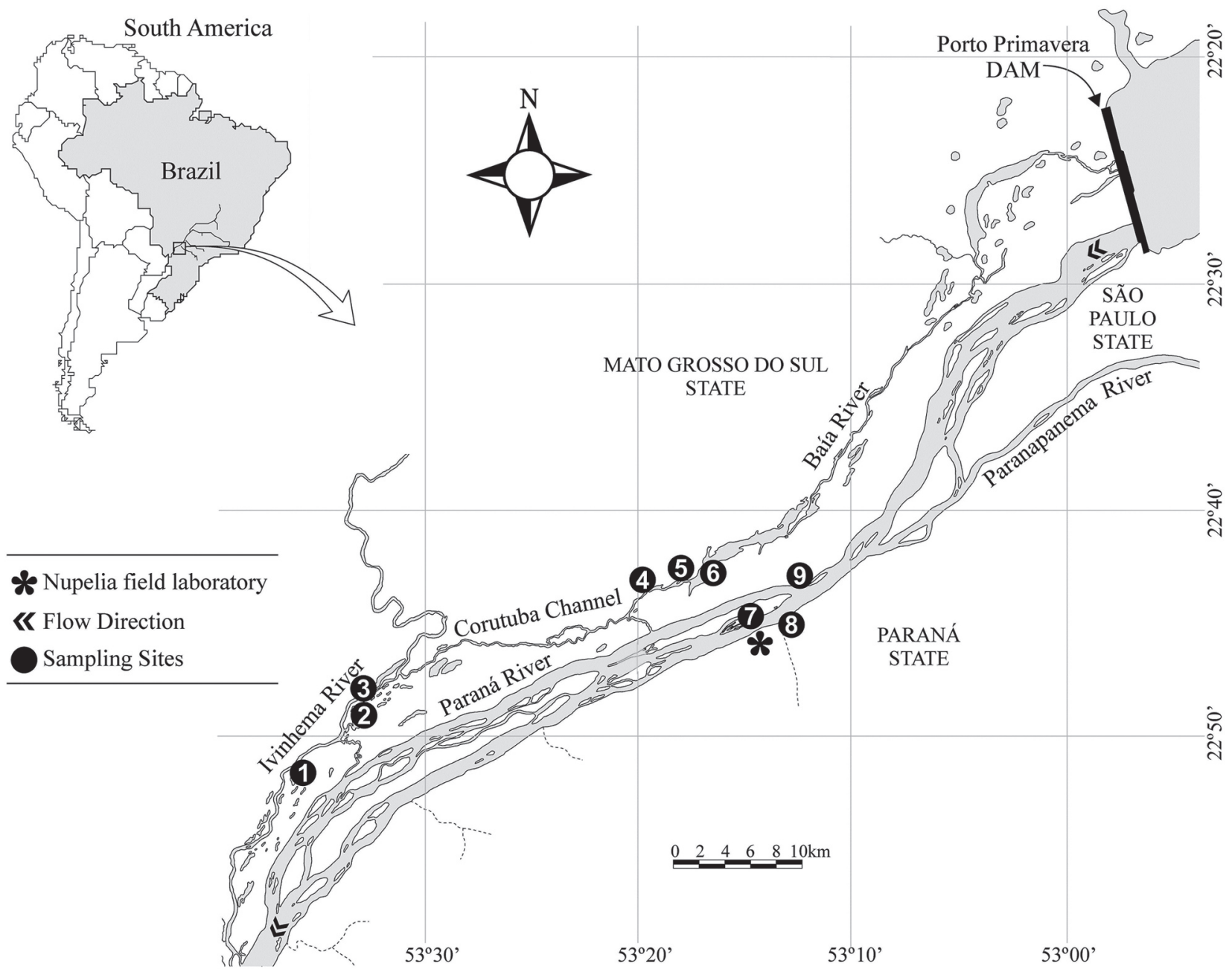

Fig. 1. Sampling sites in the upper Paraná River floodplain. Ivinhema subsystem (1. Ventura Lake, 2. Patos Lake and 3. Ivinhema River), Baía subsystem (4. Guarana Lake, 5. Fechada Lake and 6. Baía River) and Paraná subsystem (7. Pau Veio backwater, 8. Paraná River and 9. Garças Lake). 
Sampling and laboratory procedures. Samples were taken within the Long-Term Ecological Research Program (LTERP) site 6, in June and September 2013 and 2014, characterized as dry season in the region. During the dry season, catching effort is more efficient since fishes are restricted to one environment (i.e. main river channel, lakes or backwaters), rather than widely distributed along the flooded system. The effort to obtain a larger sample is due to the necessity of selecting only specimens in gonadal regeneration stage, in order to eliminate energy variations related to reproduction (Dourado \& Benedito-Cecilio, 2005; Garcia \& Benedito, 2010). Fishes were sampled with gillnets of different mesh sizes ( 3 to $16 \mathrm{~cm}$ ). Standard length (Ls, in $\mathrm{cm}$ ) and total weight (Wt, in $\mathrm{g}$ ) were obtained for each individual with a caliper rule and balance, respectively. Sex and gonadal development were registered for each individual based on the terminology proposed by BrownPeterson et al. (2011). Specimens in gonadal regeneration stage were selected for diet analysis, energy density (ED) and relative condition factor $(K n)$. Vouchers were deposited in the Coleção Ictiológica do Nupélia (NUP 6298, NUP 10609, NUP 10610, NUP 11217).

Sediment samples were collected with a modified Petersen sampler $\left(0.0345 \mathrm{~m}^{2}\right)$ on the shores (left and right) and the center of each environment (i.e. main river channel, lakes or backwaters) to characterize the systems and investigate for detritus quality. Samples were dried for 48 hours at $60^{\circ} \mathrm{C}$ and the following variables were measured: $\mathrm{pH}, \mathrm{H}^{+}\left(\mathrm{cmolc} / \mathrm{dm}^{3}\right)$, organic matter $\left(\mathrm{g} / \mathrm{dm}^{3}\right)$, carbon $\left(\mathrm{g} / \mathrm{dm}^{3}\right)$, $\mathrm{P}\left(\mathrm{g} / \mathrm{dm}^{3}\right), \mathrm{Cu}\left(\mathrm{g} / \mathrm{dm}^{3}\right), \mathrm{Zn}\left(\mathrm{g} / \mathrm{dm}^{3}\right), \mathrm{Fe}\left(\mathrm{g} / \mathrm{dm}^{3}\right), \mathrm{Mn}\left(\mathrm{g} / \mathrm{dm}^{3}\right)$, $\mathrm{Na}\left(\mathrm{g} / \mathrm{dm}^{3}\right), \mathrm{K}\left(\mathrm{g} / \mathrm{dm}^{3}\right), \mathrm{Ca}\left(\mathrm{g} / \mathrm{dm}^{3}\right), \mathrm{Mg}\left(\mathrm{g} / \mathrm{dm}^{3}\right)$ e $\mathrm{Al}\left(\mathrm{g} / \mathrm{dm}^{3}\right)$.

Stomach content was analyzed under a stereoscopic microscope and the food items identified to the lowest taxonomic level possible. Frequency of occurrence and volumetric frequency methods (Hyslop, 1980) were combined into the food index (IAi\% - Kawakami \& Vazzoler, 1980). Algae was identified in main groups, but pooled for analysis. Bacillariophyceae algae were common in stomachs with detritus/sediment, however were not considered in the analysis, given their low representation both in volume and energy content available for individuals (Martin-Jezequel et al., 2000; Pandian \& Vivekanandan, 1985).

Muscle tissue was extracted from the insertion of the dorsal fin from each individual to perform ED analysis. Samples were rinsed with distilled water, dried for 48 hours at $60^{\circ} \mathrm{C}$ and macerated into a fine and homogeneous powder. ED was measured in kilocalories per gram of dry weight (kcal/g DW) and determined in an adiabatic calorimeter (Parr 6100). All research was conducted in accordance with the policies of the Ethical Conduct Committee on Animal Use (CEUA) as administered by the State University of Maringá (Protocol 123/2010).

Nutritional status of individuals was obtained with $\mathrm{Kn}$, which corresponds to an indirect measure of energy reserves and is widely used and recognized for its effectiveness in comparative studies (Peig \& Green, 2010).
Standard length (Ls) and total observed weight (Wt) were used to calculated the species length-weight regressions using linear regression on $\log _{10}$ transformed data, in order to obtain the regression coefficients $a$ and $b$, that were used in the estimates of expected weight values (We) by the equation $\mathrm{We}=\mathrm{a}^{*} \mathrm{Lt}^{\mathrm{b}}$. Condition factor was calculated through the ratio of total weight observed and the total expected weight for a given length $\left(\mathrm{K}_{\mathrm{n}}=\mathrm{Wt} / \mathrm{We}\right)(\mathrm{Le}$ Cren, 1951). The $K n$ values were multiplied by 1000 to facilitate the interpretation of results.

Data analysis. Differences in sediment composition between subsystems were tested by permutational multivariate analysis of variance (PERMANOVA) with 4,999 permutations $(\mathrm{p}<0.05)$. SIMPER analysis was performed to verify the similarity between subsystems and to define the individual contribution of environmental factors to this similarity. Only the variables that together contributed with approximately $50 \%$ of the explained variability were held for interpretation.

Regarding measurements associated with diet composition (i.e. food items in stomach content), ED and $K n$ data we also applied separate PERMANOVA with 4,999 permutations $(p<0.05)$, to check for differences of these descriptors between the three subsystems.

The composition of the diet, ED and $K n$ values of the individuals from each year of collection were initially examined separately in order to assess possible temporal differences between subsystems through a PERMANOVA with 4,999 permutations ( $\mathrm{P}<0.05)$. As no significant differences were found between different years, values were grouped and analyzed together. All analyzes were performed in the program PRIMER $6+$ (C) PERMANOVA (Plymouth Marine Laboratory).

\section{Results}

Sediment analysis. Sediment composition was significantly different between Baía and Paraná (Pseudo-F $=2.179$, $\mathrm{p}$ $=0.0008$ ); and between Ivinhema and Baía (Pseudo-F = $2.162, p=0.004)$. No significant differences were found for sediment composition between Ivinhema and Paraná (Pseudo-F $=1.187, \mathrm{p}=0.212$ ). Baía subsystem presented significantly higher aluminum (Al), carbon and organic matter concentrations than Paraná and Ivinhema (Table 1).

Auto-ecology of the species. We sampled 168 individuals of $H$. orthonops in the upper rio Paraná floodplain (Table 2). We analyzed 102 stomachs that contained quantifiable items (Table 3). Food items that composed the diet of the species were: Algae (Zignemaphyceae, Cyanophyceae, Oedogonophyceae e Chlorophyceae), Detritus/sediment, Aquatic plant (leaves and stems of aquatic macrophytes), Microcrustacean (ostracodas and cladocerans) and Other organisms (tecameba, Bryozoan statoblast, mollusc operculum, rotifer, copepod egg and dinoflagellates). 
Table 1. SIMPER analysis for chemical composition and organic matter in the sediment of the Upper Paraná River floodplain. MSD = mean square distance. \%Cont. $=$ percentage of individual contribution of each variable. $\%$ Acum. $=$ percentage of accumulated contribution of the variables. $\mathrm{pH}=$ hydrogenionical potential, $\mathrm{H}^{+}=$total hydrogen $\left(\mathrm{cmolc} / \mathrm{dm}^{3}\right), \mathrm{MO}=$ organic matter $\left(\mathrm{g} / \mathrm{dm}^{3}\right), \mathrm{C}=$ carbon $\left(\mathrm{g} / \mathrm{dm}^{3}\right), \mathrm{P}=$ phosphorus $\left(\mathrm{g} / \mathrm{dm}^{3}\right), \mathrm{K}=\operatorname{potassium}(\mathrm{g} /$ $\left.\mathrm{dm}^{3}\right), \mathrm{Ca}=$ calcium $\left(\mathrm{g} / \mathrm{dm}^{3}\right), \mathrm{Mg}=$ magnesium $\left(\mathrm{g} / \mathrm{dm}^{3}\right), \mathrm{Al}$ $=$ aluminum $\left(\mathrm{g} / \mathrm{dm}^{3}\right), \mathrm{Cu}=$ copper $\left(\mathrm{g} / \mathrm{dm}^{3}\right), \mathrm{Zn}=\operatorname{zinc}(\mathrm{g} /$ $\left.\mathrm{dm}^{3}\right)$ and $\mathrm{Mn}=$ manganese $\left(\mathrm{g} / \mathrm{dm}^{3}\right)$.

\begin{tabular}{|c|c|c|c|c|c|c|}
\hline Grups & MSD & Variable & Baía & Ivinhema & $\%$ Cont. & $\%$ Acum. \\
\hline \multirow{7}{*}{ Bai x Ivi } & \multirow{7}{*}{32.64} & $\mathrm{Al}$ & 1.69 & 0 & 10.17 & 10.17 \\
\hline & & $\mathrm{pH}$ & 4.76 & 5.62 & 9.88 & 20.06 \\
\hline & & $\mathrm{C}$ & 42.76 & 14.57 & 9.79 & 29.84 \\
\hline & & MO & 73.72 & 25.13 & 9.79 & 39.63 \\
\hline & & $\mathrm{H}$ & 6.97 & 4.66 & 8.67 & 48.30 \\
\hline & & $\mathrm{P}$ & 21.60 & 14.31 & 8.63 & 56.93 \\
\hline & & & Baía & Paraná & & \\
\hline \multirow{7}{*}{ Bai x Par } & \multirow{7}{*}{28.31} & $\mathrm{Al}$ & 1.69 & 0.43 & 11.47 & 11.47 \\
\hline & & $\mathrm{Zn}$ & 18.73 & 9.43 & 10.00 & 21.47 \\
\hline & & $\mathrm{Cu}$ & 6.92 & 11.98 & 9.44 & 30.92 \\
\hline & & $\mathrm{C}$ & 42.76 & 22.82 & 8.78 & 39.70 \\
\hline & & MO & 73.72 & 39.35 & 8.78 & 48.48 \\
\hline & & $\mathrm{K}$ & 0.12 & 0.18 & 7.81 & 56.30 \\
\hline & & & Ivinhema & Paraná & & \\
\hline \multirow{5}{*}{ Ivi x Par } & \multirow{5}{*}{28.66} & $\mathrm{~K}$ & 0.09 & 0.18 & 11.82 & 11.82 \\
\hline & & $\mathrm{Cu}$ & 6.96 & 11.98 & 10.45 & 22.26 \\
\hline & & $\mathrm{Mn}$ & 253.00 & 187.11 & 9.80 & 32.06 \\
\hline & & $\mathrm{Ca}$ & 5.39 & 6.30 & 9.74 & 41.80 \\
\hline & & $\mathrm{Mg}$ & 1.33 & 1.42 & 9.43 & 51.23 \\
\hline
\end{tabular}

Table 2. Number of individuals of Hemiodus orthonops captured in the upper Paraná River floodplain in years 1 (June and September/2013) and 2 (June and September/2014). Ls $=$ standard length, $\mathrm{cm}=$ centimeters, $\mathrm{Wt}=$ total weight, $\mathrm{g}=$ grams, $\min =$ minimum, $\max =$ maximum .

\begin{tabular}{lccccc}
\hline Subsystems & Year 1 & Year 2 & Total & $\begin{array}{c}\text { Length } \\
\text { (Ls, cm; Min-Max) }\end{array}$ & $\begin{array}{c}\text { Weight }(\mathrm{Wt}, \mathrm{g} ; \\
\text { Min-Max) }\end{array}$ \\
\hline Ivinhema & 30 & 30 & 60 & $10.2-29.0$ & $19.6-439.5$ \\
Baía & 29 & 29 & 58 & $12.4-21.5$ & $30.5-191.6$ \\
Paraná & 34 & 16 & 50 & $10.6-27.2$ & $20.6-379.7$ \\
TOTAL & 93 & 75 & 168 & & \\
\hline
\end{tabular}

Detritus/sediment was a predominant food resource for fishes from Ivinhema and Baía subsystems (IAi $=65,4 \%$ and $\mathrm{IAi}=50,6 \%$, respectively). Algae was important for fish diet from Baía subsystem (IAi $=36,5 \%$ ), but not for Ivinhema fishes (IAi $=18,4 \%$ ) (Table 3 ).

Algae and Detritus/sediment were the most abundant food resource for specimens from Paraná subsystem (IAi $=68 \%$ and $\mathrm{IAi}=21,4 \%$, respectively), while aquatic plant had the lowest contribution (IAi $=10,6 \%$ ). Other organisms and Microcrustacean items were not important in $H$. orthonops diet, reaching less than $1 \%$ of IAi for all evaluated subsystems (Table 3).

Diet composition differed between subsystems. Fishes from Ivinhema and Paraná had the most distinct diet (Pseudo-F $=3.862, \mathrm{p}=0.0002$ ), while those from Baía and Paraná the most similar (Pseudo-F $=1.817, \mathrm{p}=0.0308$ ).

Energy density (ED). Energetic density of fishes differed between Ivinhema and the other two subsystems (Ivinhema x Baía: Pseudo-F $=6.627, \mathrm{p}=0.0002$; Ivinhema x Paraná: Pseudo-F $=4.796, p=0.0002$ ), but not between Paraná and Baía (Pseudo-F $=1,785, p=0,076$ ). Ivinhema individuals held the highest ED values while those from Paraná and Baía subsystems showed similar average (Table 4).

Table 4. Energy density (Kcal/g DW) of Hemiodus orthonops from the subsystems of the upper Paraná River floodplain. $\mathrm{DW}=$ dry weight, $\mathrm{SD}=$ standard deviation, Min $=$ minimum, $\operatorname{Max}=$ maximum.

\begin{tabular}{lcc}
\hline Subsystems & Energy density $(\mathrm{Kcal} / \mathrm{g}$ DW) $(\mathrm{Mean} \pm \mathrm{SD})$ & Min - Max \\
\hline Ivinhema & $4.97 \pm 0.12$ & $4.84-5.49$ \\
Baía & $4.83 \pm 0.09$ & $4.59-4.96$ \\
Paraná & $4.86 \pm 0.09$ & $4.71-5.11$ \\
\hline
\end{tabular}

Relative condition factor $(K n)$. Fish condition from Baía subsystem differed significantly from Paraná (Pseudo-F $=27.863, p=0.0002$ ) and Ivinhema (Pseudo-F $=38.743$, $\mathrm{p}=0.0002$ ). No differences in fish condition was detected between Paraná and Ivinhema. For both subsystems we recorded similar regression parameters, average, minimum and maximum values, while those representing Baía were lower (Table 5).

Table 3. Diet of Hemiodus orthonops in the different subsystems of the upper Paraná River floodplain. V = volume; OC $=$ occurrence; $\mathrm{IAi} \%$ = food index.

\begin{tabular}{|c|c|c|c|c|c|c|c|c|c|}
\hline \multirow{2}{*}{ Items } & \multicolumn{3}{|c|}{ Ivinhema $(n=27)$} & \multicolumn{3}{|c|}{ Baía $(\mathrm{n}=52)$} & \multicolumn{3}{|c|}{ Paraná (n = 23) } \\
\hline & $\% \mathrm{~V}$ & $\% \mathrm{OC}$ & $\% \mathrm{IAi}$ & $\% \mathrm{~V}$ & $\% \mathrm{OC}$ & $\% \mathrm{IAi}$ & $\% \mathrm{~V}$ & $\% \mathrm{OC}$ & $\% \mathrm{IAi}$ \\
\hline Algae & 17.8 & 100 & 18.4 & 34.2 & 98.0 & 36.5 & 65.2 & 100 & 68 \\
\hline Detritus/Sediment & 66 & 96.3 & 65.4 & 52.4 & 88.5 & 50.6 & 22.5 & 91.3 & 21.4 \\
\hline Aquatic plant & 14.6 & 100 & 15.0 & 12.8 & 90.4 & 12.6 & 12.3 & 82.6 & 10.6 \\
\hline Microcrustacean & 0.3 & 51.8 & 0.17 & 0.2 & 28.8 & 0.07 & 0.005 & 4.3 & 0.0002 \\
\hline Other organisms & 1.3 & 74 & 0.9 & 0.4 & 34.6 & 0.14 & 0.06 & 13.0 & 0.008 \\
\hline
\end{tabular}


Table 5. Values of the length-weight relationship parameters and relative condition factor $(\mathrm{Kn})$ of Hemiodus orthonops between the three subsystems of the upper Paraná River floodplain. $\mathrm{a}=$ intercept, $\mathrm{b}=$ slope, $K n=$ relative condition factor, $\mathrm{SD}=$ standard deviation, $\mathrm{Min}=$ minimum, $\mathrm{Max}=$ maximum.

\begin{tabular}{lcccc}
\hline Subsystems & $\mathrm{a}$ & $\mathrm{b}$ & $\mathrm{Kn}(\mathrm{Mean} \pm \mathrm{SD})$ & $\mathrm{Min}-\mathrm{Max}$ \\
\hline Ivinhema & -1.95870 & 3.17242 & $2.72 \pm 0.41$ & $1.60-3.57$ \\
Baía & -2.23157 & 3.41063 & $1.15 \pm 0.11$ & $0.96-1.57$ \\
Paraná & -1.94633 & 3.15484 & $2.88 \pm 0.40$ & $1.87-4.11$ \\
\hline
\end{tabular}

\section{Discussion}

Detritus/sediment and filamentous algae are the predominant items in the diet of $H$. orthonops from the upper rio Paraná floodplain as a whole. At Cuiabá River basin, where this species is native, Corrêa et al. (2009) categorize $H$. orthonops as detritivorous/algivorous. $H$. orthonops consumed similar food resources (i.e. same trophic categories) in native and invaded systems, indicating that the species found no food restrictions in the new environment. Besides being considered a low energetic food, the capacity to maintain stable populations through detritus/sediment ingestion provide the success of invasive fishes (Koehn, 2004; Gido \& Franssen, 2007), as it is a rarely limiting item in aquatic ecosystems (Welcomme, 1985; Moyle \& Light, 1996).

Considering the invaded system, Hemiodus orthonops consumed different food items in each of the subsystems. Besides being classified as detritivorous/algivorous species in its natural habitat, aquatic macrophytes consumption and the periphytic algae dominance on stomach content was found only in the invaded system. The availability of these food items is associated to the high transparency of Paraná subsystem water. As stated previously, this transparency has favored submerse aquatic macrophytes colonization (Thomaz et al., 2009) and by consequence the establishment of periphytic algae, mainly filamentous algae (Murakami et al., 2009; Neif et al., 2014). Macrophytes and filamentous algae were not food items observed in its native areas (Agostinho et al., 2015), nor in the tributaries (i.e. Ivinhema and Baía). These results supports our expectation of differential feeding consumption between subsystems, that are consistently linked to resource availability.

Energetic density of individuals from Ivinhema was higher than those from Baia and Paraná. The first features preserved riparian vegetation and, consequently, provide a diverse array of possible food resources to aquatic communities, maintaining ecosystem processes and dynamic (Agostinho et al., 2004; Corbetta, 2013; Pazianoto et al., 2013). Ivinhema also sustain the highest production and availability of organic detritus (Azevedo et al., 2008), preferred food items for $H$. orthonops. Even though detritus chemical composition was similar between
Ivinhema and Paraná (i.e. same nutritional quality), it was consistently more relevant to the diet of fishes from Ivinhema. Apparently, the elevated availability of algae in Paraná lead to the preferential consumption of this higher nutritional resource, rather than detritus. The results supports our first hypothesis that higher energetic density would be expected in the least affected subsystems.

Water transparency may be the keen factor underlying differences in resource availability and consumption by $H$. orthonops in the floodplain, reflected in the energy content and well-being of populations. High levels of transparency on Paraná subsystem may induce movement more frequently to search for refugee, avoiding predators for instance (Figueiredo et al., 2013; Ranaker et al., 2014; Ajemian et al., 2015). This may not occur on Ivinhema and Baía subsystems, that presents darker waters (Roberto et al., 2009). Obtaining and handling food is also an important factor (MacArthur \& Pianka, 1966), because although detritus/sediment may be a less energetic and caloric resource, its availability (Welcomme, 1985) allows fishes to spend minimum time and corporal energy to obtain and manipulate it. On the other hand, the periphytic algae ingestion demands movement between macrophyte banks and scrapping from the substrate. Those results are in accordance with optimal foraging theory (MacArthur \& Pianka, 1966), which predicts that the foraging must optimize the energy gain (Townsend \& Winfield, 1985). Thus, the effect of water transparency and obtaining food seems to negatively affect the species ED in the Paraná subsystem environments, reducing their values compared to the Ivinhema. However, more work is needed involving the feeding behavior interactions in these environments and the dispersal capacity of the species, in order to confirm our observations and increase the reliability of the results.

Considering that the energy obtained from food consumption is invested in the life maintenance, such as body growth, it was expected a proportional and positive relation between ED and $K n$. Despite the reduced ED values found for individuals of Paraná subsystem, their $K n$ reached values comparable to the Ivinhema subsystem. This result can be a consequence of the algae consumption. Although higher investment on foraging may be necessary, algae provides nutrients and elements on labile form, as nitrogen, and those that directly influence corporal growth (Bowen, 1987; Clark et al., 1990).

Baía individuals had the lowest values for both ED and $\mathrm{Kn}$, despite their good degree of conservation (Agostinho et al., 2004). Sediment analysis showed that Baía sediments are the most acids among the three subsystems, that could be the reason for the lowest ED and $K n$ values observed. The principal protein source for detritivorous species are the microorganisms added to the detritus, which present high protein content (Goldman \& Kimmel, 1978; Bowen, 1987), and improve digestion by the release of their postmortem cytoplasmic contents (Pandian, 1975). However, microorganisms generally have an optimum $\mathrm{pH}$ survival 
around 5.5 to 8 (Dickinson \& Murphy, 1998), and acid values as those found in the Baía subsystem can induce chelation, which reduces the availability of nutrients in detritus (Dickson \& Murphy, 1998). This reduction in the decomposition rates is also responsible for the high accumulation of organic matter found in Baía subsystem, directly affecting the nutrient cycling of this system (Thomaz et al., 2001).

Baía subsystem sediment presented high concentration of aluminum compared to Ivinhema and Paraná. According to Souza Filho \& Stevaux (2000) aluminum occurs naturally in the floodplain due to soil typology. However, reduced dissolved oxygen, organic matter accumulation and the presence of humic substances in high concentrations (Roberto et al., 2009) reduce the $\mathrm{pH}$ of the water and sediments in Baía. These features contribute to the release of more aluminum through chemical reactions, increasing dysfunctions of the ionic and osmotic regulation in animals (Tam et al., 1987) and other toxic effects (Gensemer \& Playle, 1999; Teien et al., 2007). Among the chronic effects of aluminum, there are the reduction in processes such as growth and reproduction, directly dependent on the body energy available (Tam et al., 1987). Levesque et al. (2002) explain that fishes, which live under chronic presence of metals like aluminum, have difficulties to convert energy obtained from food into corporal tissue, resulting in individuals with low weight and size. Thus, both the effects of acidity and aluminum in the Baía environments suggests that $H$. orthonops populations inhabiting this system presents worse body and energetic conditions, as well as the small size achieved by their individuals.

Even though Paraná is the most impacted system by the occurrence of reservoirs, it still provides a suitable environment to the developing and establishment of the invasive species $H$. orthonops. Besides showing low muscular ED values in Paraná, this species has corporal condition and size variation similar to the individuals from the highest preserved systems. This indicates that the specie does not suffer from alimentary restriction in the invaded environment, and has the ability to feed from different resources depending on their availability. We provided insightful information of the high adaptation and survivor capacity of invasiveness of $H$. orthonops in new environments. Such information can help to detect distinct environments susceptible to invasions and highlights the necessity of investigating feeding and assimilation patterns of different species with potential to colonize new habitats, as well as decision-making and employment of possible management measures. For the systems of the upper rio Paraná floodplain, preventive measures would address higher control of entry points related to the construction of reservoirs (i.e. the channel for fish passages from Itaipu dam). In this case, the situation of invasive species demands the possible closure of the fish passage, as well as alternative management actions as restoration and conservation of critical habitats downstream and upstream the dam and environmental education to prevent further fish introductions. There are no evidence that invasive species $H$. orthonops has caused adverse impacts on this ecosystem, however, traits like high abundance over the years and high trophic plasticity characterize features that urges for caution. Long-term effects of this species may still arise. Thus, we recommend that further work be carried out with this species in order to fully elucidate its effects on communities, given its high invasive potential.

\section{Acknowledgements}

Authors are grateful to the Programa de Pós-Graduação em Ecologia de Ambientes Aquáticos Continentais (PEA) and Núcleo de Pesquisas em Limnologia, Ictiologia e Aquicultura (Nupélia) of the Universidade Estadual de Maringá (UEM) for logistic support. We would like to thank the Trophic Ecology Laboratory (Nupélia/UEM) for assistance with the stomach analyzes, the Zoobenthos Laboratory (Nupélia/UEM) for the sediment sampling, to Jaime L. L. Pereira for the drawing the map and to Energetic Ecology Laboratory (Nupélia/UEM) personal for field assistance. This research was funded by LTERPsite 6 (Long Term Ecological Research Program) and Coordenação de Aperfeiçoamento de Pessoal de Nível Superior (CAPES) for a postgraduate scholarship. Animal manipulation followed the Ethics Committee of Universidade Estadual de Maringá rules.

\section{References}

Agostinho, A. A., L. Rodrigues, L. C. Gomes, S. M. Thomaz \& L. E. Miranda (Eds.). 2004. Structure and functioning of the Paraná River and its floodplain LTER-site 6 (PELD - Sítio 6). Maringá, Eduem, 275p.

Agostinho, A. A., L. C. Gomes \& F. M. Pelicice. 2007. Ecologia e manejo de recursos pesqueiros em reservatórios do Brasil. Maringá, Eduem, 501p.

Agostinho, A. A., F. M. Pelicice \& L. C. Gomes. 2008. Dams and the fish fauna of the Neotropical region: impacts and management related to diversity and fisheries. Brazilian Journal of Biology, 68: 1119-1132.

Agostinho, A. A., H. I. Suzuki, R. Fugi, D. C. Alves, L. H. Tonella \& L. A. Espindola. 2015. Ecological and life history traits of Hemiodus orthonops in the invasion process: looking for clues at home. Hydrobiologia, 746: 415-430.

Ajemian, M. J., S. Sohel \& J. Mattila. 2015. Effects of turbidity and habitat complexity on antipredator behavior of three-spined sticklebacks (Gasterosteus aculeatus): antipredator behavior in sticklebacks. Environmental Biology of Fishes, 98: 45-55.

Arenas-Ibarra, J. A., A. M. Takeda \& D. S. Fujita. 2012. O regime hidrológico do rio Ivinhema (Estado do Mato Grosso do Sul) e sua influência na assembléia zoobentônica. Acta Scientiarum Biological Sciences, 34: 47-57.

Azevedo, J. C. R., M. C. Teixeira, A. M. Santos, J. A. Leandrini \& T. A. Pagioro. 2008. Caracterização espectroscópica da matéria orgânica dissolvida da planície de inundação do alto rio Paraná. Oecologia Brasiliensis, 12: 66-77. 
Bowen, S. H. 1987. Composition and nutritional value of detritus. Pp. 192-216. In: Moriarty, D. J. W. \& R. S. V. Pullin (Eds.) Detritus and microbial ecology in aquaculture. ICLARM Conference Proceedings, Manila, Philippines, International Center for Living Aquatic Resource Management (ICLARM).

Brown-Peterson, N. J., D. M. Wyanski, F. Saborido-Rey, B. J. Macewicz \& S. K. Lowerre-Barbieri. 2011. A standardized terminology for describing reproductive development in fishes. Marine and Coastal Fisheries: Dynamics, management and ecosystem Science, 3: 52-70.

Clark, A. E., W. O. Watanabe, B. L. Olla \& R. I. Wicklund. 1990. Growth, feed conversion and protein utilization of Florida red tilapia fed isocaloric diets with different protein levels in seawater pools. Aquaculture, 88: 75-85.

Clavero, M. \& E. García-Berthou. 2005. Invasive species are a leading cause of animal extinctions. Trends in Ecology and Evolution, 20: 110.

Corbetta, D. F. 2013. Condição corporal e densidade energética de Prochilodus lineatus jovens em planície de inundação Neotropical. Unpublished Master Thesis, Universidade Estadual de Maringá, Maringá, 55p.

Corrêa, C. E., A. C. Petry \& N. S. Hahn. 2009. Influência do ciclo hidrológico na dieta e estrutura trófica da ictiofauna do rio Cuiabá, Pantanal Mato-Grossense. Iheringia, Série Zoologia, 99: 456-463.

Davis, M. A. 2009. Invasion biology. Oxford, Oxford University Press, 244p.

Dickinson, G. \& K. Murphy. 1998. Ecosystems: a functional approach. London, 190p. (Routledge introductions to environmentseries).

Dourado, E. C. S. \& E. Benedito-Cecilio. 2005. Ecologia energética de peixes: influência de fatores abióticos e bióticos. Maringá, Eduem, 53p. (Coleção Fundamentum, n. 16).

Fernandes, R., A. A. Agostinho, E. A. Ferreira, C. S. Pavanelli, H. I. Suzuki, D. P. Lima \& L. C. Gomes. 2009. Effects of the hydrological regime on the ichthyofauna of riverine environments of the Upper Paraná River floodplain. Brazilian Journal of Biology, 69(2, suppl.): 669-680.

Figueiredo, B. R. S., R. P. Mormul \& E. Benedito. 2013. Nonadditive effects of macrophyte cover and turbidity on predator-prey interactions involving an invertivorous fish and different prey types. Hydrobiologia, 716: 21-28.

Finstad, A. G., S. Einum, T. Forseth \& O. Ugedal. 2007. Shelter availability affects behaviour, size-dependent and mean growth of juvenile Atlantic salmon. Freshwater Biology, 52: 1710-1718.

Fucík, P., P. Novák \& D. Zízala. 2014. A combined statistical approach for evaluation of the effects of land use, agricultural and urban activities on stream water chemistry in small tile-drained catchments of south Bohemia, Czech Republic. Environmental Earth Sciences, 72: 2195-2216.

Fugi, R., K. D. G. Luz-Agostinho \& A. A. Agostinho. 2008. Trophic interaction between an introduced (peacock bass) and a native (dogfish) piscivorous fish in a Neotropical impounded river. Hydrobiologia, 607: 143-150.

Garcia, D. A. \& E. Benedito. 2010. Variation in energy density of Loricariichthys platymetopon (Siluriformes: Loricariidae) in the upper Paraná River basin. Neotropical Ichthyology, 8: 321-327.

Gensemer, R. W. \& R. C. Playle. 1999. The bioavailability and toxicity of aluminum in aquatic environments. Critical Reviews in Environmental Science and Technology, 29: 315-450.
Gido, K. B. \& N. R. Franssen. 2007. Invasion of stream fishes into low trophic positions. Ecology of Freshwater Fishes, 16: 457-464.

Goldman, C. R. \& B. L. Kimmel. 1978. Biological processes associated with suspended sediment and detritus in lakes and reservoirs. Pp. 19-44. In: Cairns, J. Jr., E. F. Benfield \& J. R. Webster (Eds.) Current perspectives on river-reservoir ecosystems: proceedings of a Simposium of the North American Benthological Society, 6-8 April 1977, Roanoke, Virginia.

Gutierre, S. M. M., J. R. S. Vitule, C. A. Freire \& V. Prodocimo. 2014. Physiological tools to predict invasiveness and spread via estuarine bridges: tolerance of Brazilian native and worldwide introduced freshwater fishes to increased salinity. Marine \& Freshwater Research, 65: 425-436.

Havel, J. E., C. E. Lee \& M. J. V. Zanden. 2005. Do reservoirs facilitate invasions into landscapes?. BioScience, 55: 518-525.

Holanda, F. S. R., L. G. C. Santos, C. M. Santos, A. P. B. Casado, A. Pedrotti \& G. T. Ribeiro. 2005. Riparian vegetation affected by bank erosion in the Lower São Francisco River, Northeastern Brazil. Revista Árvore, Viçosa-MG, 29: 327-336.

Hyslop, E. J. 1980. Stomach content analysis: a review of methods and their application. Journal of Fish Biology, 17: 411-429.

Johnson, P. T. J., J. D. Olden \& M. J. Vander Zanden. 2008. Dam invaders: impoundments facilitate biological invasions into freshwaters. Frontiers in Ecology and the Environment, 6: 357-363.

Júlio Júnior, H. F., C. Dei Tós, A. A. Agostinho \& C. S. Pavanelli. 2009. A massive invasion of fish species after eliminating a natural barrier in the upper Paraná river basin. Neotropical Ichthyology, 7: 709-718.

Kahilainen, K. \& H. Lehtonen. 2003. Piscivory and prey selection of four predator species in a whitefish dominated subarctic lake. Journal of Fish Biology, 63: 659-672.

Kawakami, E. \& G. Vazzoler. 1980. Método gráfico e estimativa de índice alimentar aplicado no estudo de alimentação de peixes. Boletim do Instituto Oceanográfico, 29: 205-207.

Koehn, J. D. 2004. Carp (Cyprinus carpio) as a powerful invader in Australian waterways. Freshwater Biology, 49: 882-894.

Le Cren, E. D. 1951. The length-weight relationship and seasonal cycle in gonad weight and condition in the perch (Perca fluviatilis). Journal of Animal Ecology, 20: 201-219.

Leprieur, F., O. Beauchard, S. Blanchet, T. Oberdorff \& S. Brosse. 2008. Fish invasions in the world's river systems: when natural processes are blurred by human activities. PLoS Biology, 6: 404-410.

Levesque, H. M., T. W. Moon, P. G. C. Campbell \& A. Hontela. 2002. Seasonal variation in carbohydrate and lipid metabolism of yellow perch (Perca flavescens) chronically exposed to metals in the field. Aquatic Toxicology, 60: 257-267.

MacArthur, R. H. \& E. R. Pianka. 1966. On optimal use of a patchy environment. American Naturalist, 100: 603-609.

Marchetti, M. P., T. Light, P. B. Moyle \& J. H. Viers. 2004. Fish invasions in California watersheds: testing hypotheses using landscape patterns. Ecological Applications, 14: 1507-1525.

Martin-Jézéquel, V., M. Hildebrand \& M. A. Brzezinski. 2000. Silicon metabolism in diatoms: implications for growth. Journal of Phycology, 36: 821-840.

Miller, S. J., D. T. VanGenechten \& C. E. Cichra. 2015. Lengthweight relationships and an evaluation of fish-size and seasonal effects on relative condition $\left(\mathrm{K}_{\mathrm{n}}\right)$ of fishes from the Wekiva River, Florida. Florida Scientist, 78: 1-19. 
Moyle, P. B. \& T. Light. 1996. Biological invasions of fresh water: empirical rules and assembly theory. Biological Conservation, 78: 149-161.

Murakami, E. A., D. C. Bicudo \& L. Rodrigues. 2009. Periphytic algae of the Garças Lake, Upper Paraná River floodplain: comparing the years 1994 and 2004. Brazilian Journal of Biology, 69(2, suppl.): 459-468.

Neiff, E. M., R. D. L. Behrend \& L. Rodrigues. 2014. Investigations on periphytic algae: comparing distinct years in the presence and absence of submerged macrophytes. Brazilian Journal of Biology, 74: 521-522.

Pandian, T. J. 1975. Mechanism of heterotrophy. Pp. 61-249. In: Kinne, O. (Ed.) Marine ecology: a comprehensive, integrated treatise on life in oceans and coastal waters. London, WileyInterscience, v.2: Physiological mechanisms. Part 1.

Pandian, T. J. \& E. Vivekanandan. 1985. Energetics of feeding and digestion. Pp. 99-124. In: Tytler, P. \& P. Calow (Eds.) Fish energetics: new perspectives. Baltimore, Maryland, The Johns Hopkins University Press.

Pazianoto, L. H. R., M. L. S. Souza, A. L. Veronezzi \& E. Benedito. 2013. Influência do ambiente no conteúdo calórico e na condição fisiológica de duas espécies migradoras de peixes neotropicais. Iheringia, Série Zoologia, 103: 206-213.

Peig, J. \& A. J. Green. 2010. The paradigm of body condition: a critical reappraisal of current methods based on mass and length. Functional Ecology, 24: 1323-1332.

Pelicice, F.M. \& A.A. Agostinho. 2008. Fish-passage facilities as ecological traps in large Neotropical rivers. Conservation Biology, 22: 180-188.

Ranaker, L., J. Persson, M. Jönsson, P. A. Nilsson \& C. Brönmark. 2014. Piscivore-prey fish interactions: mechanisms behind diurnal patterns in prey selectivity in brown and clear water. PLoS ONE, 9: e102002 (1-8).

Roberto, M. C., N. F. Santana \& S. M. Thomaz. 2009. Limnology in the Upper Paraná River floodplain: large-scale spatial and temporal patterns, and the influence of reservoirs. Brazilian Journal Biology, 69(2, suppl.): 717-725.

Santos, N. C. L., T. N. Medeiros, A. A. F. Rocha, R. M. Dias \& W. Severi. 2014. Uso de recursos alimentares por Plagioscion squamosissimus - piscívoro não-nativo no reservatório de Sobradinho-BA, Brasil. Boletim do Instituto de Pesca, 40: 397-408.

Souza Filho, E. E. \& J. C. Stevaux. 2000. O componente físico da planície alagável do alto rio Paraná. Pp. 13-60. In: Agostinho, A. A., S. M. Thomaz \& K. Nakatani (Coords.) A Planície de inundação do alto rio Paraná: SITE 6 - PELD/CNPq. Maringá: Núcleo de Pesquisas em Limnologia, Ictiologia e Aquicultura. (Relatório técnico anual).

Suzuki, H. I., A. A. Agostinho, D. Bailly, M. F. Gimenes, H. F. Júlio-Júnior \& L. C. Gomes. 2009. Inter-annual variations in the abundance of young-of-the-year of migratory fishes in the Upper Paraná River floodplain: relations with hydrographic attributes. Brazilian Journal of Biology, 69(2, suppl.): 649-660.
Tam, W. H., L. Birkett, R. Makaran, P. D. Payson, D. K. Whitney \& C. K. C. Yu. 1987. Modification of carbohydrate metabolism and liver vitellogenic function in brook trout (Salvelinus fontinalis) by exposure to low $\mathrm{pH}$. Canadian Journal of Fisheries and Aquatic Sciences, 44: 630-635.

Tank, J. L., E. J. Rosi-Marshall, N. A. Griffiths, S. A. Entrekin \& M. L. Stephen. 2010. A review of allochthonous organic matter dynamics and metabolism in streams. Journal of North American Benthological Society, 29: 118-146.

Taylor, B. W. \& R. E. Irwin. 2004. Linking economic activities to the distribution of exotic plants. Proceedings of the National Academy of Sciences, 101: 17725-17730.

Teien, H. -C., B. Salbu, F. Kroglund, L. S. Heier \& B. O. Rosseland. 2007. The influence of colloidal material on aluminium speciation and estimated acid neutralising capacity (ANC). Applied Geochemistry, 22: 1202-1208.

Thomaz, S. M., P. Carvalho, A. A. Padial \& J. T. Kobayashi. 2009. Temporal and spatial patterns of aquatic macrophyte diversity in the upper Paraná river floodplain. Brazilian Journal of Biology, 69(2, suppl.): 617-625.

Thomaz, S. M., G. Pereira \& T. A. Pagioro. 2001. Microbial respiration and chemical composition of different sediment fractions in waterbodies of the upper Paraná river floodplain, Brazil. Brazilian Journal of Biology, 61: 277-286.

Tirelli, V., D. Borme, F. Tulli, M. Cigar, S. Fonda Umani \& S. B. Brandt. 2006. Energy density of anchovy Engraulis encrasicolus L. in the Adriatic Sea. Journal of Fish Biology, 68: 982-989.

Townsend, C. R. \& I. J. Winfield. 1985. The application of optimal foraging theory to feeding behaviour in fish. Pp. 67-98. In: Tytler, P. \& P. Calow (Eds.) Fish energetics: new perspectives. Baltimore, Maryland, The Johns Hopkins University Press.

Vitule, J. R. S. \& V. Prodocimo. 2012. Introdução de espécies não nativas e invasões biológicas. Estudos de Biologia, 34: 225237.

Vitule, J. R. S., F. Skóra \& V. Abilhoa. 2012. Homogenization of freshwater fish faunas after the elimination of a natural barrier by a dam in Neotropics. Diversity and Distributions, 18: 111120.

Welcomme, R. L. 1985. River fisheries. Rome, FAO, 330p. (FAO Fisheries technical paper, 262).

Zambrano, L., E. Valiente \& M. J. Vander Zanden. 2010. Food web overlap among native axolotl (Ambystoma mexicanum) and two exotic fishes: carp (Cyprinus carpio) and tilapia (Oreochromis niloticus) in Xochimilco, Mexico City. Biological Invasions, 12: 3061-3069.

Submitted October 11, 2015 Accepted January 12, 2016 by Emili García-Berthou 